\title{
アスパラギン酸の化学と医薬品への応用
}

\author{
松 本 和 男*・関雅 彦*
}

\section{Chemistry of Aspartic Acid and Its Application to Drug-synthesis}

Kazuo Matsumoto* and Masahiko SeKı*

This review deals with the chemistry of aspartic acid derivatives and its utilization for drug-syntheses. It should be noted in particular that "Aspartylation", in which the aspartic acid skeleton is introduced into the target molecules by the use of various aspartic acid synthons, provides a useful methodology for the preparation of the pharmaceuticals.

Key words : Aspartic acid; Amino acid; Aspartylation; Aspartic acid synthon; Carbon-carbon bond formation; Antibiotic; ACE inhibitor; CNS action; Penicillin; Carbapenem; Hypolipidemic agent.

\section{1. はじめに}

近年，合成化学技術およびバイオテクノロジーの目ざ ましい進歩によって, 多くのアミノ酸が安価に製造供給 されるようになってきだ”。これに伴い，アミノ酸は単 に食品添加物, 動物飼料添加物や輸液として用いられる のにとどまらず医薬品を含む種々の有用化合物の合成原 料として広く利用されるようになってきた2)。

中でもアスパラギン酸は多量に生産される安価なアミ ノ酸の一つであり,また分子内に官能基としてアミノ基, 2 つのカルボキシル基, 活性メチンおよび活性メチレン を有する四炭素骨格からなる多官能性化合物であること から，特に反応活性種として注目されるものである。さ らに, アスパラギン酸は光学活性物質であることから, 光学活性化合物の合成原料としても極めて魅力ある機能 性化合物といえる(図 1)。

アスパラギン酸を標的化合物の炭素骨格に組み込むこ とをAspartylation と名づけ，以下その方法論を中心に 紹介する。

具体的に Aspartylation を行うに当っては，アスパラ ギン酸の各種官能基を適宜活性化する必要がある。特に

\section{* 田辺製薬 (株) 応用生化学研究所}

* Research Laboratory of Applied Biochemistry, Tanabe Seiyaku Co., Ltd.

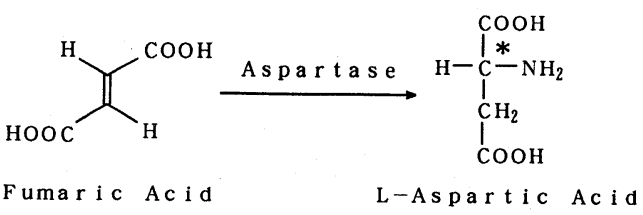

Fig. 1

炭素一炭素結合形成反応に利用する場合には，その活性 化がキーポイントになる。最近，このアスパラギン酸骨 格の反応活性化に関する研究が盛んになってきた。即ち, 活性化方法により，ある時はカチオン性活性種として, またある時はアニオン性活性種として利用できる所謂 “アスパラギン酸シントン”としての有効利用が注目さ れてきた。

本稿では，アスパラギン酸の化学的な特徵を図 2 に示 すように官能基別に分類し，それらを利用した反応およ びそれらから合成される化合物の医薬品への応用例につ いて概説したい。 


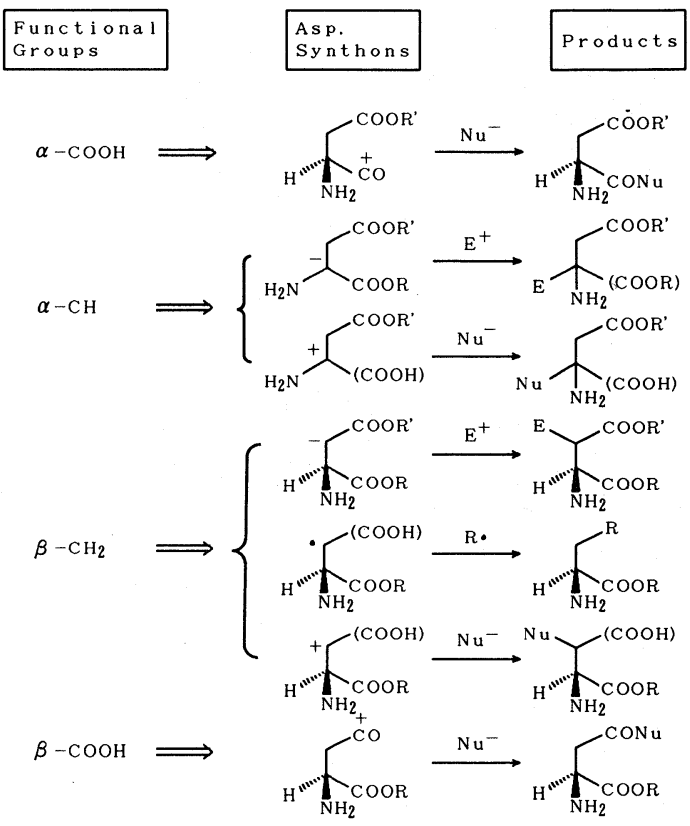

Fig. 2

\section{2. アスパラギン酸の特性と製法}

アスパラギン酸は必須アミノ酸には数えられていない が代謝されやすく, TCA サイクル, オルニチンサイクル, 核酸の生合成等において重要な役割を果たすアミノ酸で ある3)。

$\mathrm{DL}$-アスパラギン酸はフマール酸やマレイン酸をアン モニアでアミノ化することで得られる ${ }^{4)}$ 。光学活性体の 合成に関しては不斉合成もいくつか報告されている が，工業的製法としては，L体については酵素法が，ま た，D体については光学分割法または酵素法が用いられ ている。即ち，L-アスパラギン酸は安価なフマール酸を 原料としアスパルターゼを含有する固定化微生物を作用 させることにより田辺製薬 (株)において工業生産されて
いる $\left(\right.$ 図 1) ${ }^{6}$ 。 一方， D-アスパラギン酸は $\mathrm{DL}$ 体から優先 晶析による光学分割 ${ }^{7)} に よ り$ 得られるが, DL 体にアスパ ラギン酸 $\beta$ 脱炭酸酵素を作用させることにより L-アス パラギン酸を L-アラシンに変換し，未反応物を精製す ることによっても得られる8

\section{3. アスパラギン酸の化学}

3.1. $\alpha$-カルボン酸の利用 アスパラギン酸の $\alpha-$

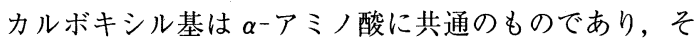
れを利用するためには $\beta$-カルボキシル基の適切な保護 が必要である。保護基としては $t$-ブチル基を含む低級 アルキルエステルやベンジルエステルのように加水分解 または水素化分解により容易に脱離できるものが好適で ある。 $\alpha$-カルボキシル基の最も簡単な利用例としては 甘味剂“アスパルテーム”のような $\alpha$-アスパルチルペ プチドがよく知られている゙が，最近になって炭素-炭 素結合形成にも利用されている。ここでは, ペプチド合 成への利用を割愛し，炭素-炭素結合形成についてのみ 紹介する。

一般に， $\alpha$-アミノ酸の $\alpha$-カルボキシル基をアシル基 に変換した, 所謂 $\alpha$-アミノケトン誘導体は種々の生理 活性化合物の汎用中間体として有用である ${ }^{10)}$ 。特に，そ の光学活性体は有用性が高くそれらの変換法についての 報告が散見されるようになっだ1)。

著者らは, Aspartylationの利用のひとつとして $\beta$-カ ルボキシル基を保護したアスパラギン酸から相当する

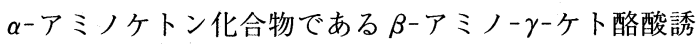
導体を合成した。即ち， $N$-アルコキシカルボニルアス パラギン酸 $\beta$-エステル ( 2 ) に五塩化リンを作用させて, in situ に生成した酸クロリド体 (3) を反応活性種として 用い,これにベンゼン類を塩化アルミニウムの触媒下に 反応 (Friedel-Crafts 反応)させるとラセミ化を伴うこと なく光学活性なアミノケトン体 (4) が得られる ${ }^{12)}$ (図 3)。ここで得られたアミノケトン化合物 (4) は光学活性

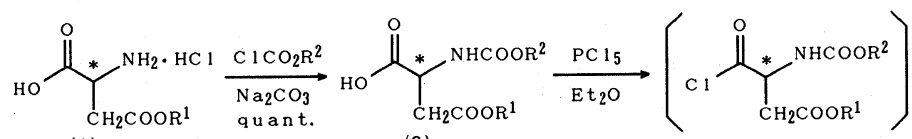

(1)

(2)

(3)

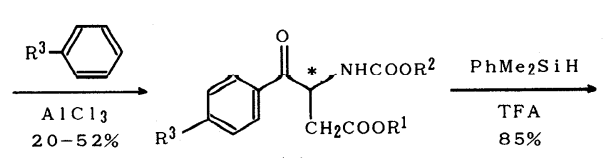

(4)

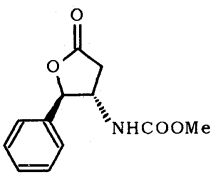

(5) $\operatorname{trans} / \mathrm{c}$ is $=92 / 8$ $>95 \%$ e. e.

Fig. 3 
なアミノラクトン化合物 $(5)^{13)}$, さらに非天然アミノ酸 およびアミノ糖の合成中間体として興味がもたれる ${ }^{14)} 。$

アスパラギン酸の酸クロリドの代わりにアズラクトン 化合物 (6)を Friedel-Crafts 反応に付しても $N$-アシル $\beta$-アミノー $\gamma$-ケト酪酸誘導体 (7) を好収率に得ることが できる ${ }^{15)}$ (図 4)。アズラクトン誘導体はラセミ化しやす

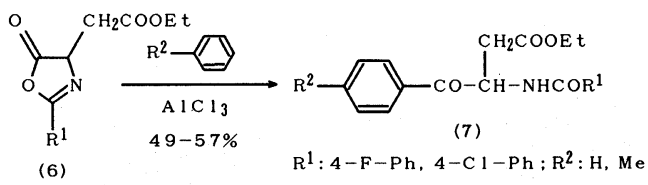

Fig. 4

いため光学活性体の合成は困難であるが, 後述するよう に, この $\beta$-アミノー $\gamma$-ケト酪酸誘導体はオキサゾール 酢酸やイミダゾール酢酸等のヘテロ環化合物の合成に極 めて有用である。

3.2. $\alpha$-メチンの利用 動物の歯牙, 目の水晶体 などに含まれるアスパラギン酸の光学純度を調べること によりその年代や老化の程度を推定することができると いわれている16)。それはアスパラギン酸の $\alpha$ 位炭素が比 較的ラセミ化しやすい特性があるからである。この $\alpha-$ 炭素の反応性を炭素-炭素結合形成に生かしていくこと は合成化学上魅力ある利用法と考えられる。

$\alpha-ア ミ ノ$ 酸の $\alpha$ 位炭素の活性化にはアミノ基をイソ ニトリル基に換えた所謂 $\alpha$-イソニトリル化合物 (8)が 好適である ${ }^{17)}$ (図 5)。

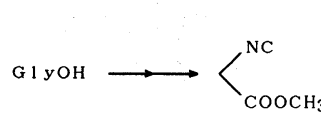

(8)

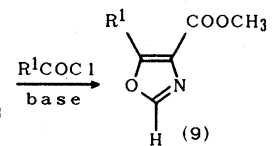

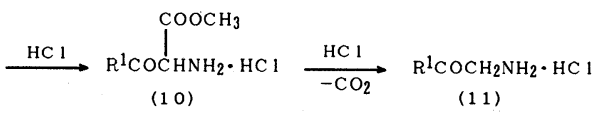

Fig. 5

その応用例の一つとして, アシル化剂との反応によっ て得られたオキサゾール誘導体 (9)を加水分解して $\alpha-$ アシルアミノ酸誘導体 (10)に導く合成法がある ${ }^{18)}$ (図 5)。本法はアスパラギン酸骨格にも適用できる。例えば, イソニトリル化合物 (13)にトリエチルアミンの存在下ベ

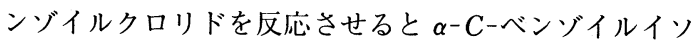
ニトリル化合物 (14)が生成する。これをギ酸で加水分解 し， $\alpha-C$-ベンゾイル-N-ホルミル化合物 (15) に導き,
さらに酸加水分解すると $\beta$-アミノー $\gamma$-ケト酪酸誘導体 (16)が得られる ${ }^{15)}$ 。本法も結果的にアスパラギン酸骨格 を導入する, 所謂, 一つの Aspartylation と言える ${ }^{15)}$ (図 6) 。

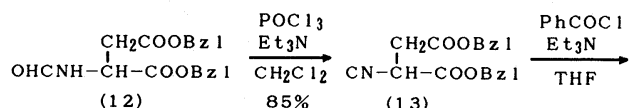

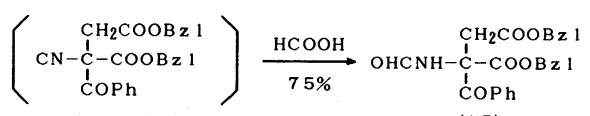

$$
\begin{aligned}
& \text { (14) }
\end{aligned}
$$

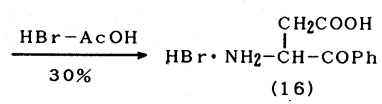

$$
\begin{aligned}
& \text { (15) }
\end{aligned}
$$

Fig. 6

さらに，著者らはアニオン性活性種としてアズラクト ン誘導体に着目した。古くから，アミノ酸アズラクトン を経由するDakin-West 反応による $\alpha$-アミノケトン誘 導体の合成法はよく知られており，アスパラギン酸を用 いた Dakin-West 反応についても報告があるが，副生物 $(18 ， 19)$ を伴い目的とする $\beta$-アセチルアミノ $\gamma-\gamma$-ケト 酪酸誘導体 (17) の生成する収率は低い結果となる ${ }^{19)}$ (図 7)。

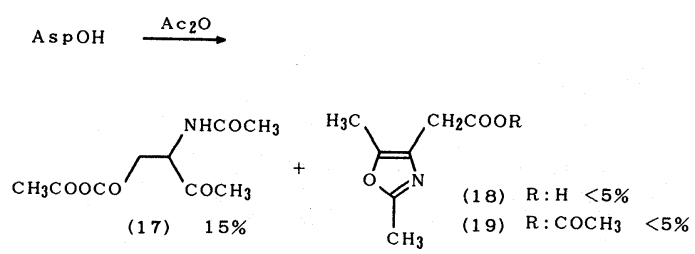

Fig. 7

また，W . Steglich らは，N-アシルアスパラギン酸無 水物 (20) を出発原料とし無水酢酸中で短時間加熱すると テトラヒドロフロ [3,4-d]オキサゾール-5-オン (22丸が, また無水酢酸中酢酸存在下で加熱すると $2(5 H)$-フラノ ン(23)が得られ，さらに無水酢酸中で 3 -ピコリンまた はトリエチルアミンとジメチルアミノピリジン存在のも とに加熱すると $6 H-1,3-$ オキサジンー6-オン (24)が得ら れることを確認している。各化合物の生成機構は図 8 に 示したようにいずれも $\beta$-アミノー $\gamma$-ケト酪酸 (21)を中 間体としている20)。

一方, $N$-アシルアスパラギン酸 $\beta$-エステル (25)に無 水酢酸を反応させると $\beta$-アシルアミノー $\gamma$-ケト酪酸誘 導体 (26) が高収率に得られると報告されている ${ }^{21)}$ が(図 


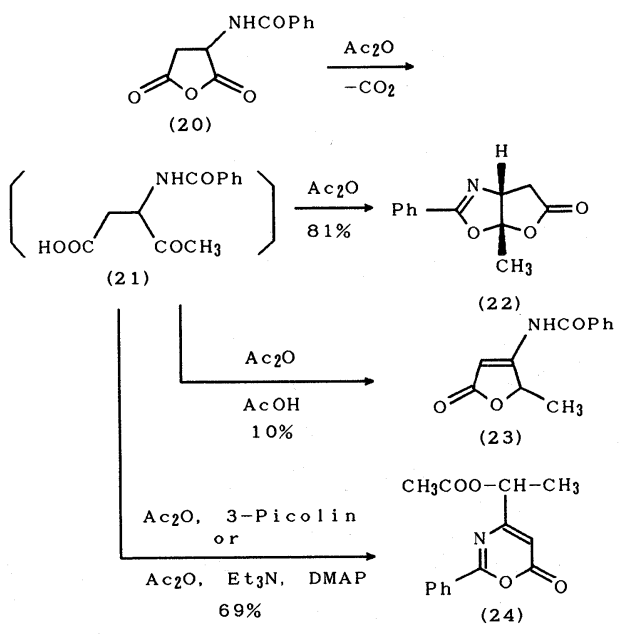

Fig. 8

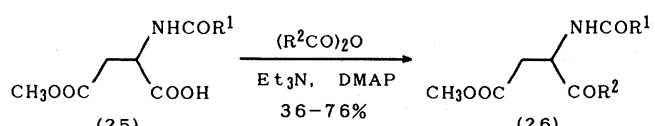

$\mathrm{R}^{1}$ : Cycloalkyl, Styryl $R^{2}$ : Methy 1, Ethy 1, Propy

Fig. 9

9)，アシル基は限定される。もし，アズラクトンを純粋 に単離でき，各種アシル化剤を任意に使用できれば，本 法は $\beta-ア ミ ノ-\gamma-ケ ト$ 酪酸誘導体の合成に極めて有用 な方法になる。一般に，この種の飽和アズラクトンは油 状物質であることが多く不安定である。上記目的には高 純度のアズラクトンが必要であり，そのためには結晶性 化合物であることが望ましい。著者らはこの目的に従っ て検討した結果, $N$-ベンゾイルアスパラギン酸誘導体 (28) から相当するアズラクトン (6)を高純度かつ高収率 に合成することができた ${ }^{15)}$ (図 10)。

$$
\text { そこで，このアスパラギン酸アズラクトン }(6 \mathrm{c}) \text { を用 }
$$
い, Dakin-West 反応による Aspartylation を検討した。

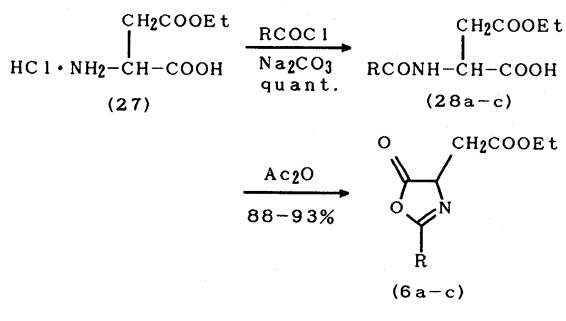

Fig. 10
塩基としてトリエチルアミンを用い, 酸クロリドとして 後述する医薬品合成の目的のためにフロイルクロリドを 反応させた。その結果，最初の中間体 $O$-アシル体 (29) が $67 \%$ で単離できた。これにピリジンを加えて加熱す ると転位反応が生起し中間体として $C-$ アシル体 (30)が 得られた。さらに，これに酢酸を加えて加熱すると脱炭 酸が起こり, 目的とする $\beta$-アミノ $-\gamma$-ケト酪酸 (31) を 高収率 $(87 \%)$ で得ることができた。一方，塩基および溶 媒にピリジンを用いるとワンポット反応により一挙に Cーアシル体 (30) までの変換が進行し目的物を高収率に 得ることができ，Aspartylationの実用化の道が拓けた。 (図 11, 表 1)。
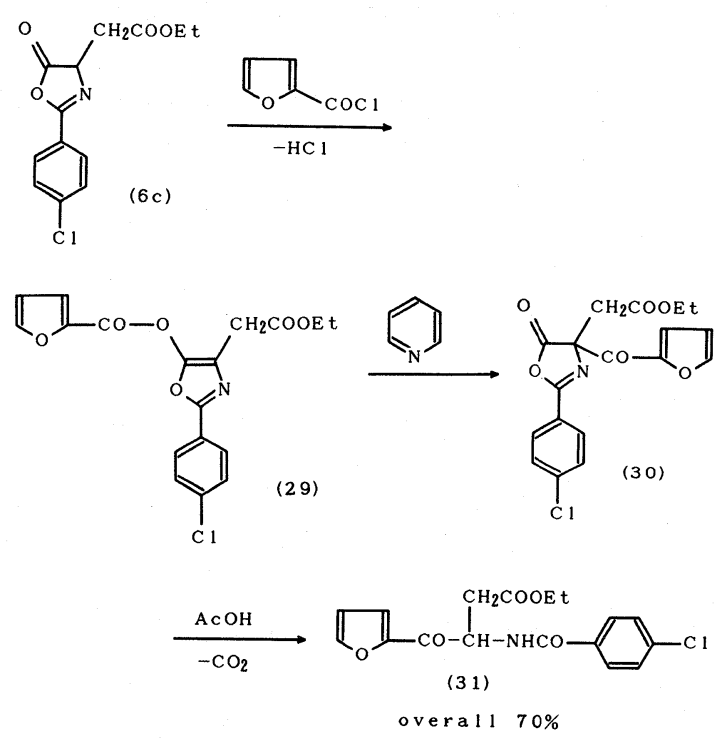

Fig. 11

Table 1

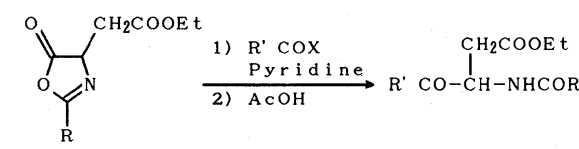

\begin{tabular}{c|l|l|c}
\hline run & \multicolumn{1}{|c|}{$\mathrm{R}^{\prime}$} & \multicolumn{1}{c|}{$\mathrm{R}$} & Yield(\%) \\
\hline 1 & $\mathrm{Ph}$ & $\mathrm{Ph}$ & 85 \\
2 & $\mathrm{Ph}$ & $4-\mathrm{Cl}-\mathrm{Ph}$ & 75 \\
3 & $4-\mathrm{Cl}-\mathrm{Ph}$ & $\mathrm{Ph}$ & 80 \\
4 & 2-Furyl & $4-\mathrm{Cl}-\mathrm{Ph}$ & 70 \\
5 & 2-Thienyl & $4-\mathrm{Cl}-\mathrm{Ph}$ & 78 \\
6 & 3-Pyridyl & 4- $\mathrm{Cl}-\mathrm{Ph}$ & 70 \\
7 & Cyclopentyl & 4-Cl-Ph & 87 \\
\hline
\end{tabular}




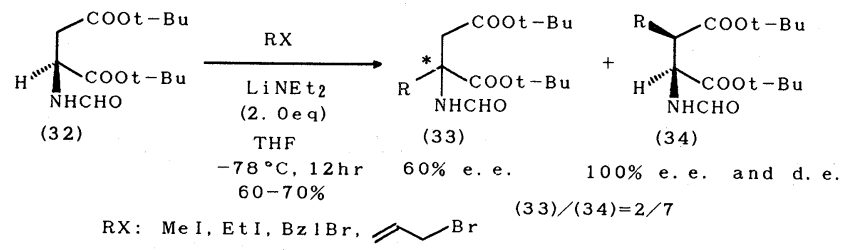

Fig. 12

$\alpha$-メチンへの親電子付加に基づく光学活性化合物の 合成として, D. Seebach らはリチウムジエチルアミド 在存下に $N$-ホルミルアスパラギン酸ジ $t$-ブチルエス テル (32)のアルキル化を行った ${ }^{22)}$ 。生成物は $\alpha$-および $\beta$-アルキル体の混合物 $(\alpha / \beta=2 / 7)$ であったが, $\alpha$-体 (33) をカラムで精製単離すると光学活性体 $(60 \%$ e.e.) が得 られる(図 12)。彼らは, この不斉反応はエノラート塩 の軸不斉 (図 13) か, あるいはこのエノラート塩とその 前駆体 (32) とのキラルな錯体形成に起因するものと考え た。

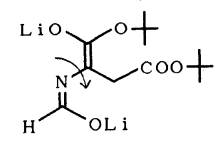

Fig. 13

また，彼らは，L-アスパラギン酸から 2 位に $t$-ブチ ル基を有する 5-イミダゾリジノン酢酸誘導体 (42)に導 き，これにアルキル化を行い高い不斉収率で $\alpha$-アルキ ル体 (43) を得た ${ }^{23)}$ (図 14)。本反応の高立体選択性は,
歪みのかかった 5 員環での 1,3-不斉誘導に基づくと考

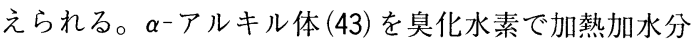
解することにより $\alpha$ 位が重水素またはアルキル置換し た光学活性アスパラギン酸 (44) が得られる。なお， $\alpha^{-}$ アルキルアスパラギン酸の不斉合成については，この他 にU. SchÖllkopf らの報告がある ${ }^{24)}$

以上の反応はアスパラギン酸のアニオン性活性種とし て利用する反応例であるが，カチオン性活性種としても 利用できる。その一例として著者らはセリンへの変換を 行った。Hunsdiecker 反応による熱反応はラセミ化を伴 うと考え，特にKolbe 型電解酸化を行った。即ち， Nアシルアスパラギン酸 $\alpha$-エステル化合物 (45) を含水溶 媒中で電解酸化すると低収率ながら目的とする $N$-アシ ルセリンエステル(47)が得られた。しかし, 副生物が多 く実用化には至らなかった ${ }^{25)}$ (図 15)。一方，この研究 により脱炭酸後に生成する $\beta$ 位カチオン (またはカチ才 ンラジカル）(46) は不安定でありすぐデヒドロアラニン 誘導体およびそれからの 2 次的反応が進行することがわ かった。他方，例えばアラニンのような中性アミノ酸の $N$-アシル体を同様に電解酸化すると好収率で $\alpha$-メトキ

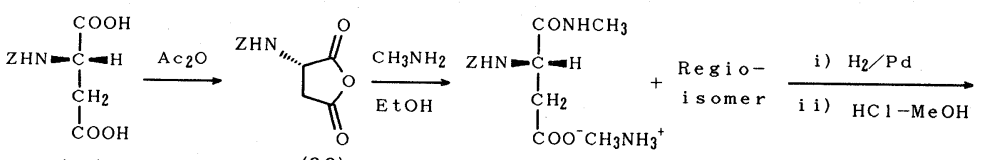

(35) (36) (37)

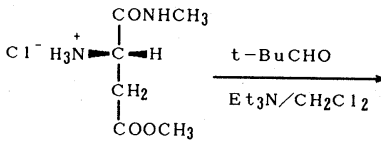

(38)

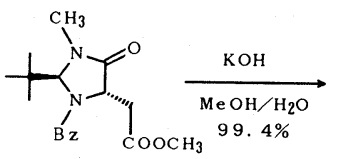

(41)

$17 \%$ f rom (35)<smiles>COC(=O)C[C@H](N=CC(C)(C)C)C(=O)OC</smiles>

(39)

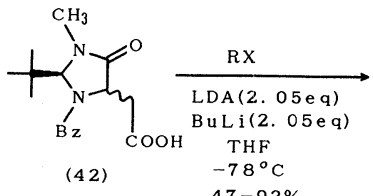

(42)

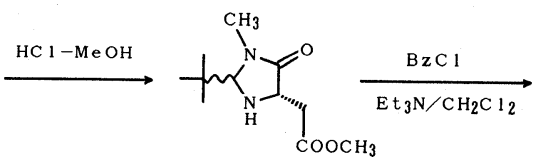

(40)

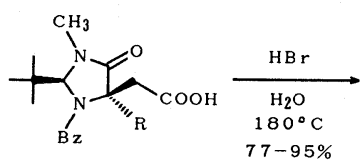

(43)

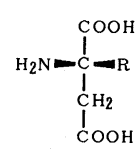

(44)

$\mathrm{RX}: \mathrm{MeI}, \mathrm{Bz} 1 \mathrm{Br}>95 \%$ d. e. $\mathrm{R}: \mathrm{Me}, \mathrm{Bz} 1, \mathrm{D}$ $\mathrm{RX}: \mathrm{D}_{2} \mathrm{O} 76 \%$ d. e.

Fig. 14 


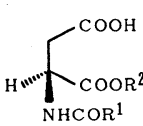

(45)
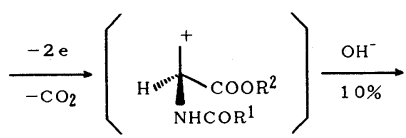

(46)

Fig. 15

シ化合物が生成することがわかった。この知見を基にし て, $N-$ アシル- $\alpha$-アミノマロン酸半エステル誘導体を 電解酸化することにより容易に $\alpha$-メトキシまたはアセ トキシアミノ酸誘導体, 所謂 “カチオン性アミノ酸活性 種”を得ることができた ${ }^{26)}$ 。

前述の知見をアスパラギン酸に適用するとウラシルを 合成することができると考え，N-エトキシカルボニル アスパラギン (48) をメタノール中で電解酸化した。その 結果, 脱炭酸が容易に進行し $\beta$-メトキシー $\beta$-アラニン アミド (49)が高収率で得られた。これを環化するとウラ シル (50)が高収率で合成できた。また，N-エトキシカ ルボニルアスパラギン (48) から誘導されるジヒドロオ ロット酸 (51) を電解酸化してもウラシル (50) を合成する ことができた27)(図 16)。

3.3. $\beta$-メチレンの利用 アスパラギン酸の $\beta$ 位 活性メチレンも合成化学的に興味がもたれる。その理由 の一つとして $\alpha$ 位不斉炭素を利用して 1,2 -不斉誘導が できる点があげられる。そのためには $\alpha$ 位の光学活性 を保持し $\beta$-エステルエノレートを選択的に発生させる
必要がある。

前述したように, D. Seebach らは $N$-ホルミルアスパ ラギン酸ジ $t$-ブチルエステル (32) から $\beta$-アルキルアス パラギン酸誘導体 (34) を合成したが $\alpha$-アルキル体 (33) が副生した ${ }^{22)}(\beta / \alpha=7 / 2)$ (図 12)。

その改良法として，H. Rapoport らはアミノ基の保護 基としてかさ高い 9- (9-フェニルフルオレニル) 基 $(\mathrm{PhFl}$ 基)を導入して位置選択的に $\beta$-アルキル化を行った ${ }^{28)}$ 。 さらに，当該化合物 (53) はアルデヒド化合物 (54), $\gamma$ ラクタム化合物 (55) にも変換できる(図 17)。

J.E. Baldwin らは $N$-ベンジルオキシカルボニルアス パラギン酸 $\alpha$ - $t$-ブチルー $\beta$-エステル (56) を用い $\beta$-アル キル体 (57) を位置選択的に合成した ${ }^{299}$ 。

親電子剂としてアルデヒドを用いて得た $\beta$-ヒドロキ シカルボン酸体 (59) にトリベンジルホスフィン/DEAD を作用させると $\beta, \gamma$-不飽和アミノ酸 (61) が得られる ${ }^{30)}$ (図 18)。

G.J. McGarvey らは $\beta$-メチレンのアルキル化のジア ステレオ選択性の向上を目的として環状化合物に着目し た。即ち, アスパラギン酸無水物 (62) から $\alpha$-カルボニ ル基のみを還元して得られるアミノラクトン体 (63)を LDA でジアニオンとしてメチル化した ${ }^{311}$ 。その結果, 高立体選択的にトランス体 (64) (トランス/シス =11/1) を得た。さらに，このアミノラクトン体(63)からオキサ ゾリン誘導体 (65) を合成して, $\mathrm{NaN}(\mathrm{TMS})_{2} / \mathrm{HMPA}+$

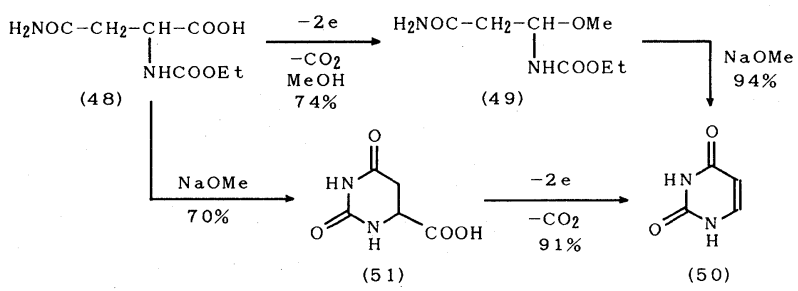

Fig. 16

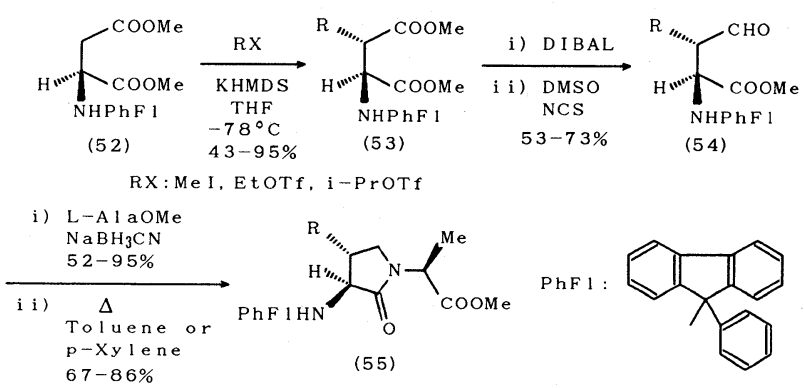

Fig. 17 

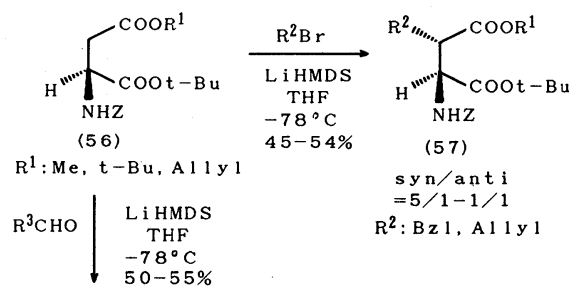

(57)

s n $/$ ant i

$=5 / 1-1 / 1$

$\mathrm{R}^{2}: \mathrm{Bz} 1, \mathrm{~A} 11 \mathrm{y}$
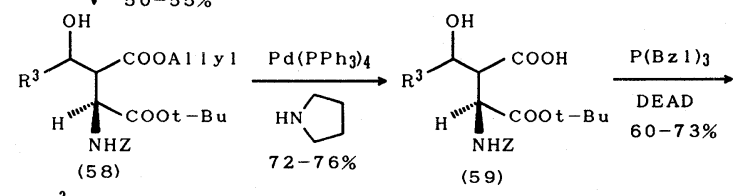

$\mathrm{R}^{3}: \mathrm{Et}, \mathrm{Ph}$

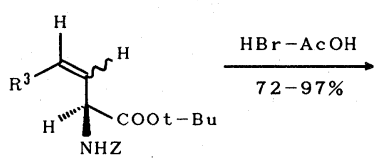

(60)

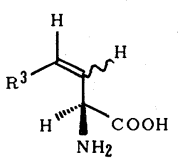

(6 1)
Fig. 18
THF 系でメチル化を行うと syn 体 (66) が，また NaN (TMS) ${ }_{2} / \mathrm{THF}$ 系では anti 体 (67) がいずれも高立体選択 的に得られた(図 19)。この立体選択性は, キレーショ ン制御と立体電子制御により説明されている(図 20)。 さらに，彼らはこの反応を amphotericin B の側鎖の合 成に利用している。また,このアミノラクトンは microcystin-LR の $\beta$-アミノ酸部分 (Adda) ${ }^{32)}$ ，シスーカルバ ペネム ${ }^{33)}$, モノバクタム ${ }^{34}$ 等の不斉合成にも利用されて いる。

著者らは, $N$-アシルアスパラギン酸 $\alpha$-エステルまた は $\alpha$-アミド体 (68) を脱水閉環して得られる5-エトキシ または 5 -ピロリジノオキサゾール酶酸誘導体 (70) の活 性メチレンへのアルキル化, 続く酸加水分解により $\beta$ アルキルアスパラギン酸誘導体 (72) を得ている ${ }^{35}$ ) (図 21)。

同じく活性メチレンの利用法の一つとして, 新規ピ ロール類の合成もある ${ }^{36)}$ 。即ち，アスパラギン酸アズラ
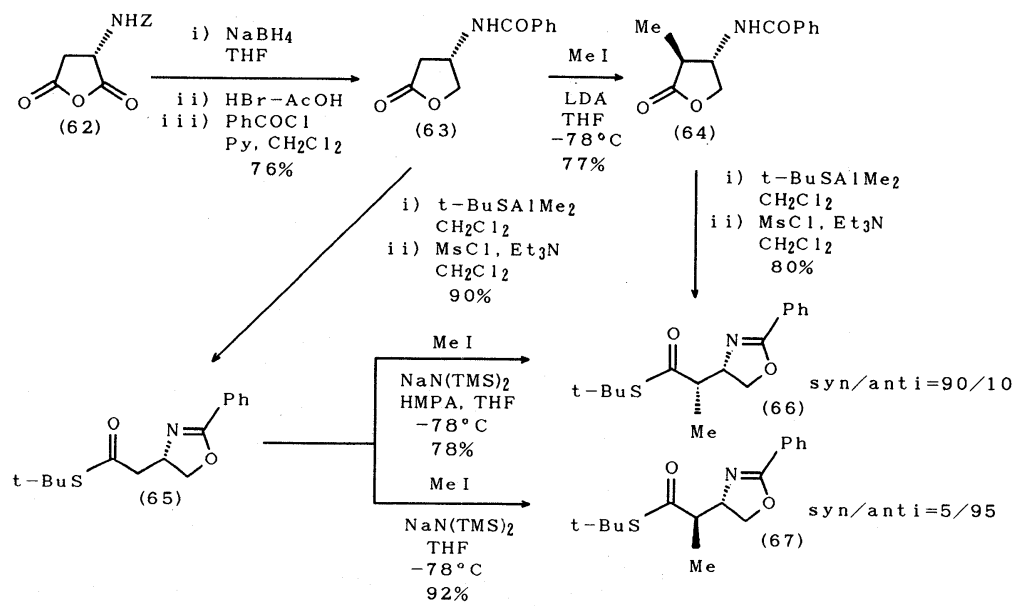

Fig. 19

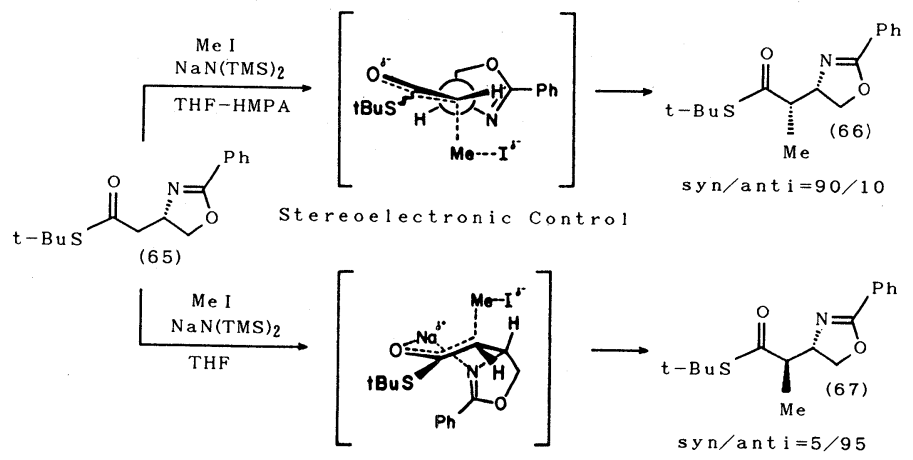

Chelation Control

Fig. 20 
クトン (6) より得られるジアミド $\beta$-エステル体 (73)に 3 モル比の Vilsmeier 試薬を $60^{\circ} \mathrm{C}$ で作用させると 4 置 換 $\beta$-アミノピロール誘導体 (77) が高収率で得られる。 また, 73 を低温で脱水閉環すると5-アミノオキサゾー ル酢酸 (74)を得ることができる。74にVilsmeier 試薬を 作用させても 77 を得ることができるので，上記反応の 鍵中間体はオキサゾール化合物 (74)であると考えられる (図 22)。

アスパラギン酸の酸化的 $\beta$ 位脱炭酸で得られる $\beta$ 位 カチオンは極めて不安定であり, 合成化学的利用が困難 なことは既に述べたが，これに代わるものとして著者ら はアスパラギン酸の $\beta$-カチオン等価体であるデヒドロ アラニン誘導体への変換に着目した。

一方, 生合成反応において, $\mathrm{L}$-アスパラギン酸を基質 としてアスパラギン酸 $\beta$-脱炭酸酵素を作用させると脱 炭酸を伴って $\mathrm{L}$-アラニンが生成することは上述し, $\mathrm{L}-$ アラニンの製法として田辺製薬(株)に扔いて工業化され ている ${ }^{37)}$ 。この脱炭酸酵素の反応メカニズムとして図 23 のようなピリドキサル系を介した反応経路が報告さ れている ${ }^{38)}$ 。著者らはこの中間体，デヒドロアラニン誘 導体(81)の生成に着目した。一方, オキザロ酢酸 (84) と 光学活性ベンジル系アミン (85) からなる Schiff 塩基 (86) の接触還元によるアスパラギン酸の不斉合成の過程でア ラニンが副生することを知った ${ }^{39}$ (図 24)。

そこで,これら $2 つ の$ 知見から，アスパラギン酸誘導 体からデヒドロアラニン誘導体を合成できると考えた。 具体的に， $N$-アシルアスパラギン酸 $(91)$ を選び，これ に含水メタノール中アンチホルミンを作用させると，八 ロゲン化, 脱八ロゲン化水素, 脱炭酸が一挙に起こり $N$-アシルデヒドロアラニン (95)を好收率に得ることが できた ${ }^{10)}$ (図 25)。

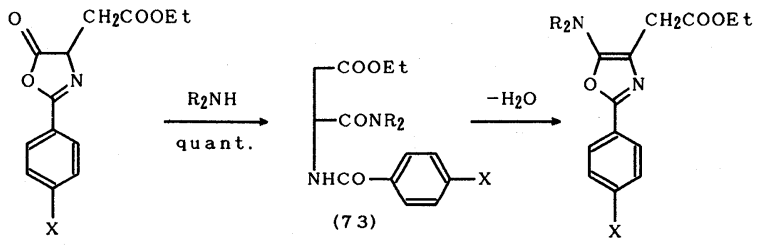

(6) (74)
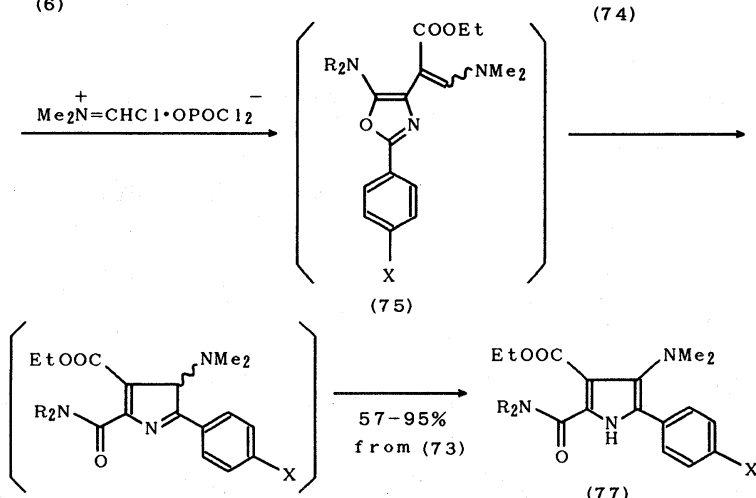

(76)

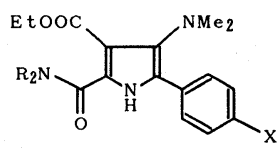

(77)

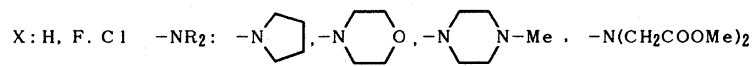

Fig. 22

また，N-アシルアスパラギン酸ジエステル (96)にト リエチルアミン存在下 $t$-ブチルハイポクロライドを作 用させるとデヒドロアスパラギン酸エステル (97)，(98) を得ることができる ${ }^{41}$ (図 26)。

これらの化合物は $\beta$-カチオン性活性種としての利用 と共にアミノ基含有ジエノフィルとして有用である。例 えば，四塩化スズの存在下にシクロペンタジエンとの反 応を行うとノルボルネン誘導体 (99)，（100）が収率良く 合成できる゙2)。

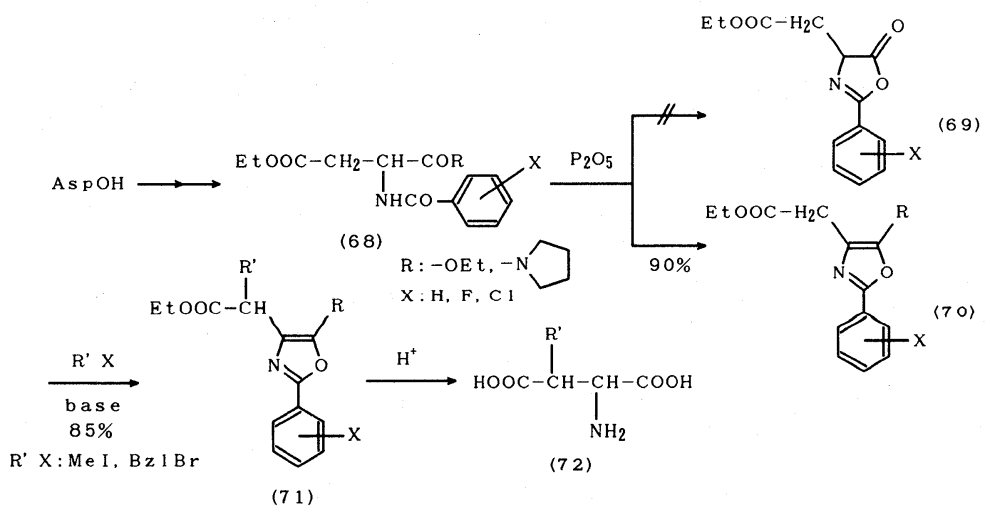

Fig. 21 


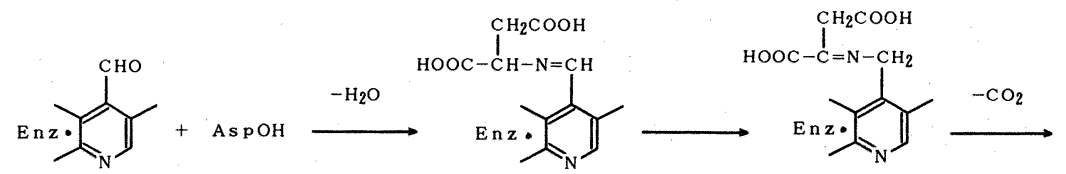

(78)

(79)

(80)

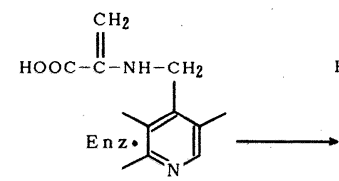

(81)<smiles>Cc1cnc(C)c(CNC(C)C(=O)O)c1C</smiles>

(82)

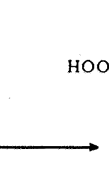

HOOC

$\mathrm{CH}_{3}$

Fig. 23

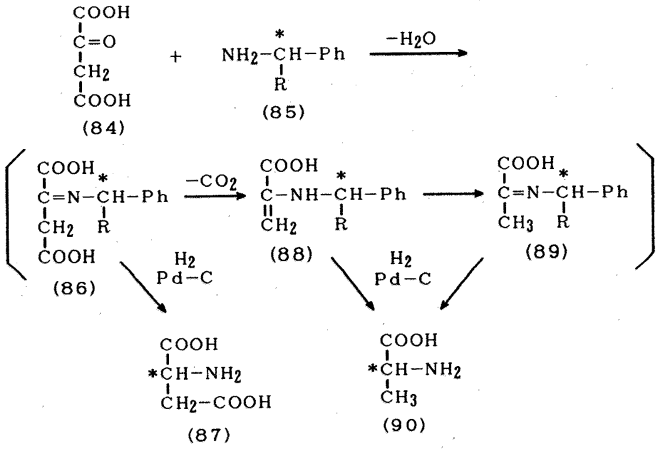

Fig. 24

D.H.R. Barton らはアスパラギン酸と $N$-ヒドロキシ -2-チオピリジンを縮合した後，光反応により $\beta$-脱炭酸 を行い $\beta$-炭素上にラジカル (103)を発生させた。これに 種々のマイケルアクセプターを反忘させ好収率にスル フィド化合物 (104)を得ている。これを MCPBA 酸化し, 次いでスルホキサイドを熱脱離させ $\gamma, \delta$ 不飽和アミ， 酸 (105) を高収率に得ている。さらに， $\alpha$-位の不斉炭素 が全くラセミ化しないことを利用して $\alpha$-アミノアジピ ン酸(106)の不斉合成も報告している ${ }^{43)}$ (図 27)。

3.4. $\beta$-カルボン酸の利用 $\beta$-ケト $-\alpha$-アミノ酸誘

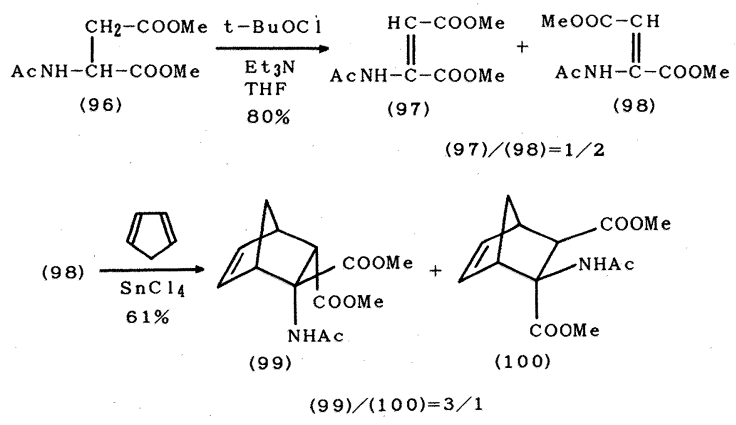

Fig. 26

導体は各種生理活性物質の有用な合成中間体である。こ れも Aspartylation により合成できる。その実例を述べ る。

$N$-アシルアスパラギン酸無水物 (108) を FriedelCrafts 反応に付すと選択的に $\beta$ 位に炭素-炭素結合形成

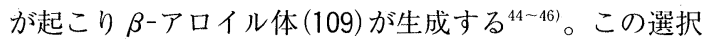
性はアミノ保護基の電子吸引性と立体的要因により決ま ると考えられている(図 28)。これらの $\beta$-アロイル体 (109)は, ドーパミンアンタゴニスト ${ }^{45)}$, 抗パーキンソ ン氏病薬 ${ }^{46}$ 等の合成にも利用される。

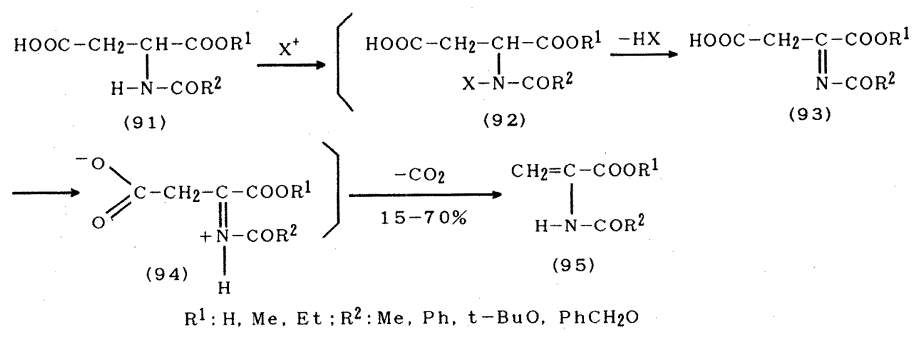

Fig. 25 

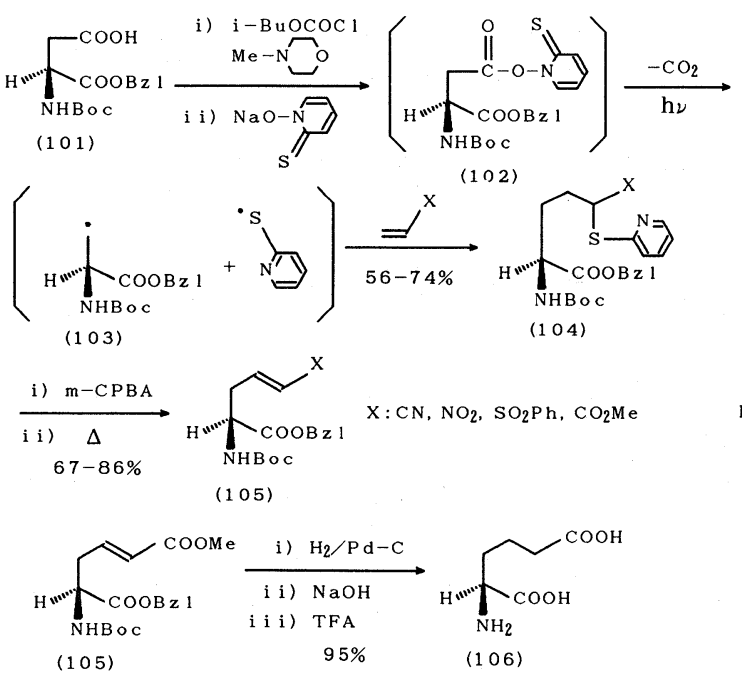

Fig. 27
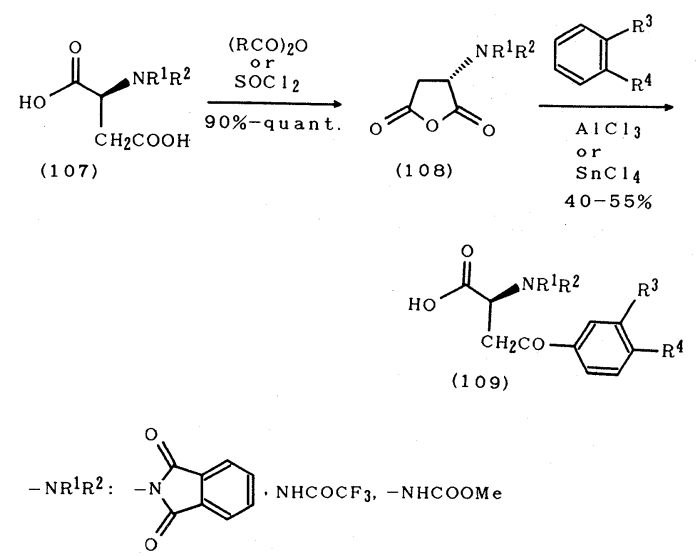

$R^{3}, R^{4}: H, H ; O M e, ~ O M e ; C l$, OMe

Fig. 28

アスパラギン酸の $\beta$-カルボキシル基をアルデヒドに 変換した $\beta$-セミアルデヒド体も有用性が高く種々の有 機合成に利用されている77.48)が，メチオニンを利用した 方がより簡単である ${ }^{18)}$ と考えられるので， $\beta$-セミアルデ ヒド体に関しては本稿では割愛する。

アスパラギン酸の $\beta$-カルボキシル基の利用のひとつ としてアミノ基への変換がある。その最も一般的な力法 として Hoffmann 転位友応がある。例えば, 脇らは酸化 剤としてビス(トリフルオロアセトキシ)フェニルヨウ素 を作用させると高収率に目的物 (111)が得られることを 見い出した (99) (図 29)。また, P.A. Bartlettらは, 図 30

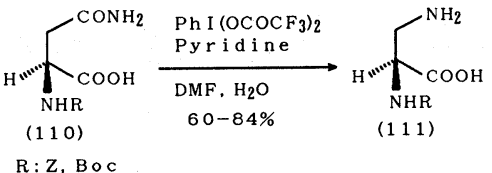

Fig. 29

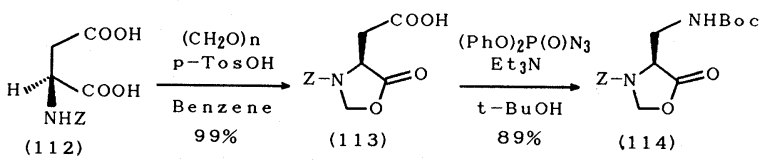

Fig. 30

に示したようなCurtius 転位を報告している50)。一方， 脱保護容易な保護基としてベンジルオキシカルボニル基 $(Z$ 基)を用いた。 $Z$-アスパラギンにアンチホルミンを 作用させた場合には Hoffmann 転位と閉環が一挙に起こ りオキソイミダゾリジンカルボン酸誘導体 (116)が高収 率に得られ, ジアミノプロピオン酸への変換は起こらな ( ${ }^{51}$ (図 31)。

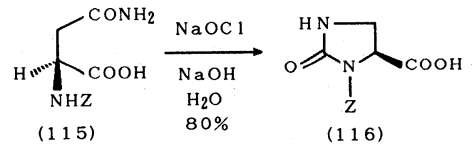

Fig. 31

得られた 2,3-ジアミノプロピオン酸は各種有用化合 物の合成中間体となる。そのひとつとして, $\beta$-アミ 基を水酸基に変換するとセリンが得られる。アミノ基を 水酸基に変換する一般法はジアゾ化であるが，七リン合 成に関しては $\alpha-ア ミ ノ$ 基の保護基が問題となる。変換 反応に耐える最も安定な保護基としてトシル基があげら れる。即ち, $N$-トシルアスパラギン (117)から $N-\alpha-$ ト シルジアミノプロピオン酸を経由して $N$-トシルセリン （118）を高収率に得ることができるが，脱トシルには難 点が残っている ${ }^{521}$ (図 32)。セリンの合成については, この他にCurtius 転位 ${ }^{53)}$ や Baeyer-Villiger 酸化を用いた

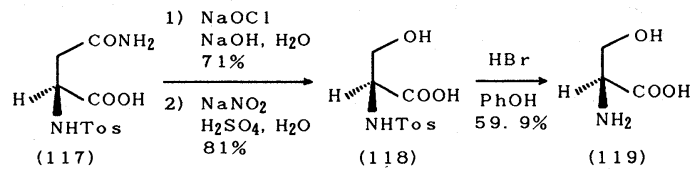

Fig. 32 

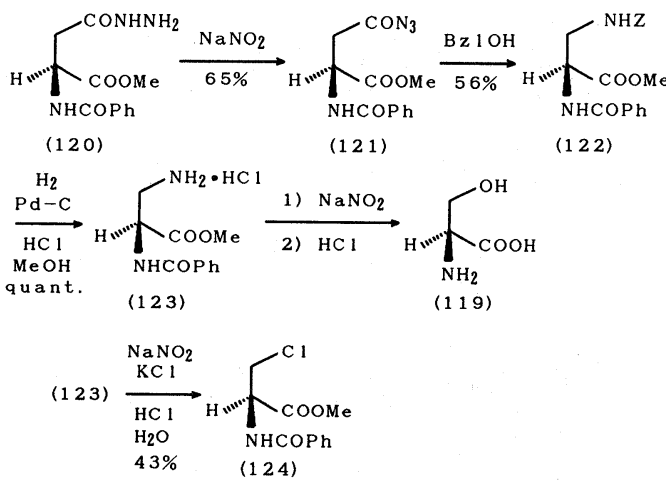

Fig. 33

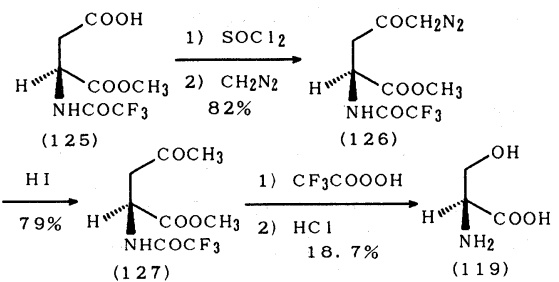

Fig. 34

方法がある ${ }^{54)}$ が実用化には至っていない(図 33，34)。

アスパラギン酸の $\beta$-アミド誘導体を選択的に還元す るとホモセリン (129)が得られる。その還元法としては 塩化リチウムの存在下に鉛電極を用いた電解還元が好適 である ${ }^{55)}$ (図 35)。H. Rapoport らは，アミノ保護基にか

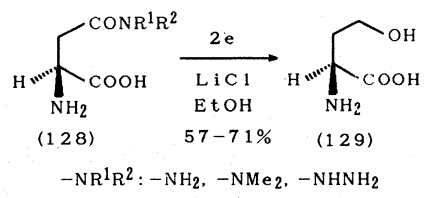

Fig. 35

さ高い 9- (9-フェニルフルオレニル) 基を導入した $\beta$-ア ルキルアスパラギン酸ジエステル誘導体(130)の $\beta$-エス テル基をDIBAL 還元してホモセリン誘導体(131)を合成 している(図 36) ${ }^{28\}}$ 。

3.5. $\alpha$-アミノ基の利用 $\alpha$-アミノ基の最も簡単 な利用法としては，ジアゾ化反応によるハロゲン化合物 や水酸化化合物への誘導があげられる。山田らは，アス パラギン酸またはその $\beta$-エステル体 $(132)$ の硫酸水溶液 に臭化ナトリウムを作用させ， $\alpha$-ブロモコハク酸誘導 体 (133) を立体配置を保持したまま好収率に得ている ${ }^{56)}$

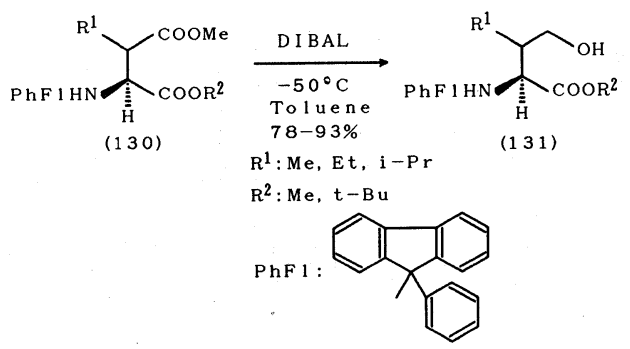

Fig. 36

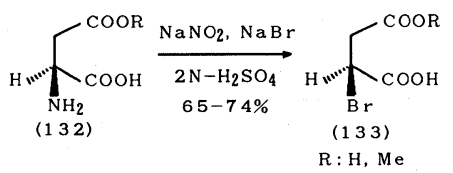

Fig. 37

(図 37)。

水酸化反応については，宮沢らは L-アスパラギンに 酢酸水溶液中覀硝酸ナトリウムを作用させ $\mathrm{L}$-リンゴ酸 アミド(135)を高収率で得ている。これをアンチホルミ ンで Hoffmann 転位させると $(S)$-イソセリン (136)に導 くことができる57) (図 38)。一方，アスパラギン酸から

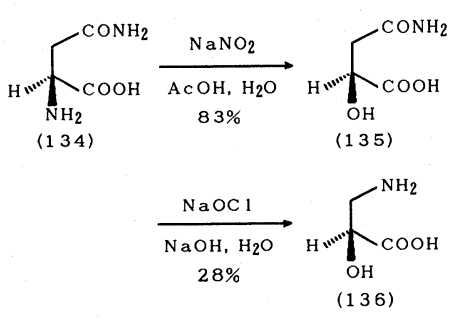

Fig. 38

同様にして合成できる L-リンゴ酸 $\alpha$-ベンジルエステル (137)にジフェニルリン酸アジド (DPPA) を作用させ (S) -2-オキソオキサゾリジンカルボン酸ベンジルエス テル (138) を得, これをアルカリ加水分解すると $(S)$-イ ソセリン (136) が好収率で合成できる ${ }^{58)}$ (図 39)。

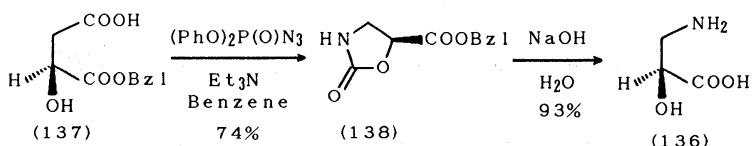

Fig. 39 


\section{4. 医薬品合成への応用}

アスパラギン酸は生体にとって重要なアミノ酸のひと つであり，アミノ酸輸液にも不叮欠の成分のひとつであ る。

䀢薬品としては, 心疾患, 低カリウム血症型周期性四 肢麻瘒の治療薬にアスパラギン酸カリウムマグネシウム 塩, アスパラギン酸カリウム塩, アスパラギン酸マグネ シウム塩が市販されている。また，貧血症治療薬として アスパラギン酸第一鉄塩なども市販されている ${ }^{599}$ 。

アスパラギン酸誘導体そのものが医薬㣍として使われ ている例は少ないが, 最近医薬品合成に利用した研究が 多くみられるようになった。

本節では，前節に述べたアスパラギン酸の化学をを医薬 品合成に利用した例を紹介する。

利用法としては，医薬品の竍核(基本骨格)と考えられ る部分と側鎖と考えられる部分があるが，それらを一括 して薬効別に紹介する。

4.1. ペニシリン系抗菌薬 田辺製薬(株)に扔いて は, ペニシリン系抗菌薬としてアスポキシシリン (145) を開発した ようにペニシリン骨格に側鎖としてDーアスパラギン誘 導体を組み込んだものである。D-アスパラギン酸 $\beta$-メ チルエステル (139)のアミノ基をNPS 化した後， $\beta$ 位を
N-メチルアミド化する。これを DCC 法により $p$-ヒド ロキシフェニルグリシンと縮令した後，6-アミノペニシ ラン酸 (6-APA) (143) を縮命するとアスポキシシリン (145) が得られる。

4.2. ペネム系抗菌薬 カルバペネム兴格を存する チエナマイシン (152) はその抗菌スペクトルの広さと抗 菌力の強さで特に注目されており"，1980年，T.N. Saltzmann らにより不斉合成された ${ }^{62)}$ 。その合成上の問 題点は，連続する 3 湖の不齐炭素の立体制御と極めて歪 みの大きなカルバペネム環の構築であった。彼らは, そ の合成戦略として，L-アスパラギン酸を出発原料とし， グリニャール試薬による $\beta$-ラクタム環の形成， 6 位へ のアセチル基の立体選択的な導入とその不齐還元， ジア ゾカルベン挿入文心に基づくカルバペネム環の閉䍗岱忍 を用い，その全令成に成功した(図 41)。

4.3. ACE 阻害薬 最近, 抗高压薬としてアンジ オテンシン変換酵素 $(\mathrm{ACE})$ 阻棐薬が注目されてきた 田辺製薬 (株)ではカプトプリル(153)をリード化令物
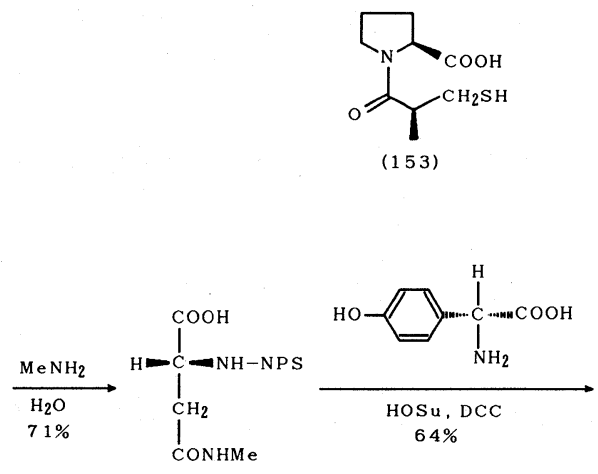

(1 399$)$

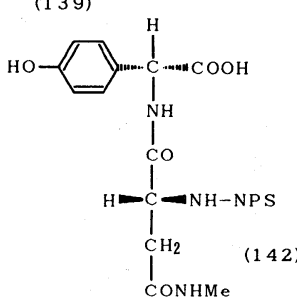

(140)
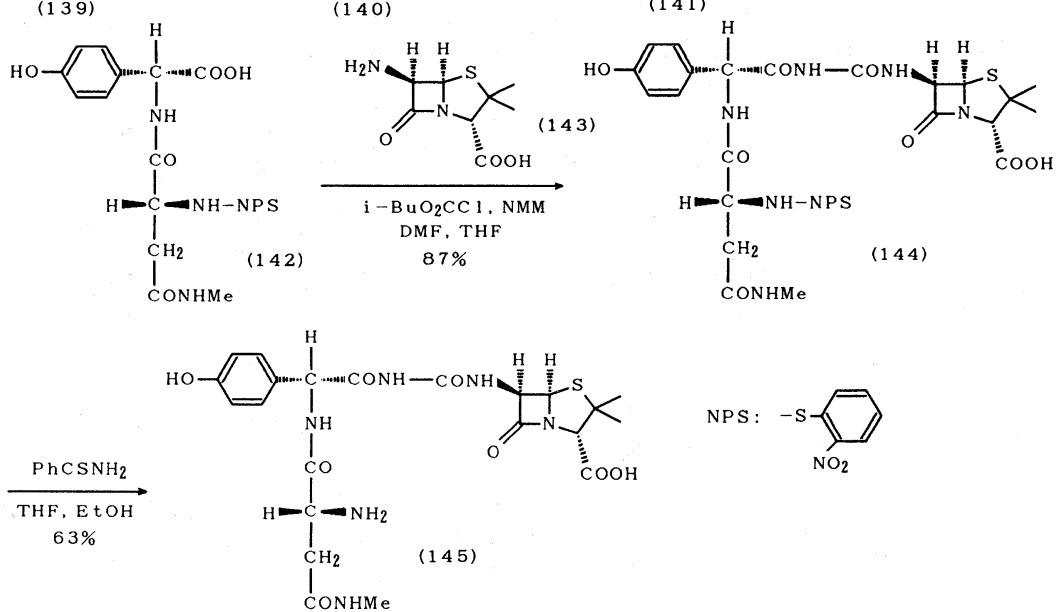

Fig. 40 


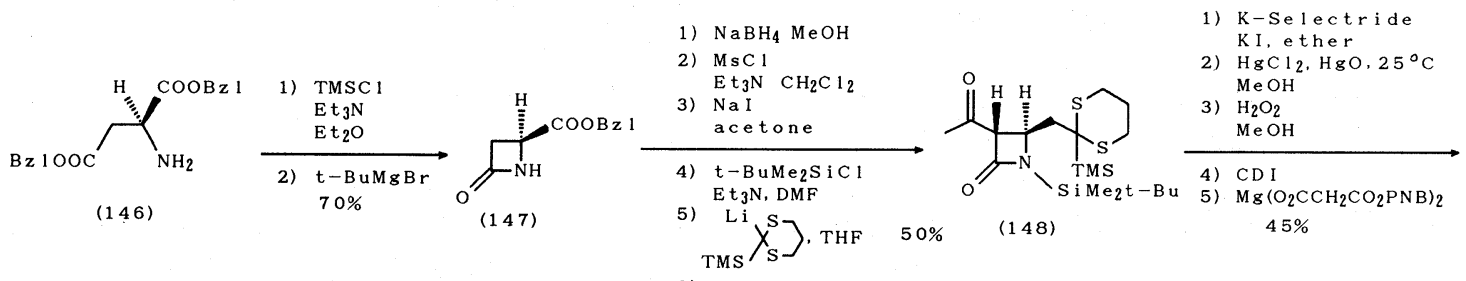

6) $\mathrm{N}-\mathrm{Ac}-\mathrm{imidaz} 01 \mathrm{e}$ LDA, THF, $-78^{\circ} \mathrm{C}$

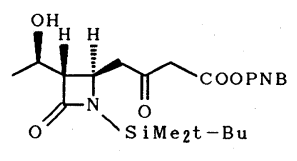

(149)

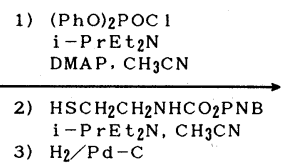
$70 \%$
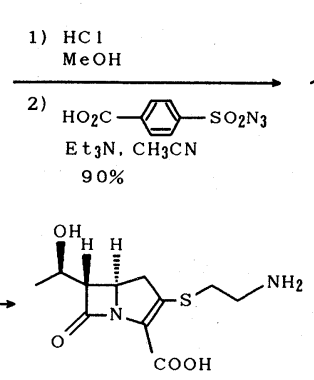

(152)

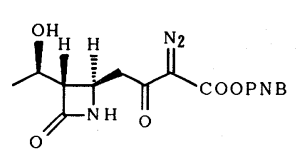

(150)

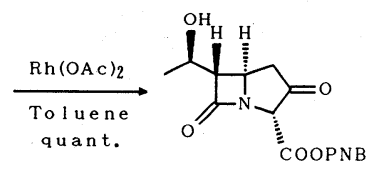

(151)

Fig. 41

としてそのプロリン部分およびメルカプトプロピオン酸 部分を種々変換した化合物を数多く合成してきた。その 過程においてオキソイミダゾリジン環は極めて有効な部 分構造であることを見い出した。その後，オキソイミダ ゾリジン環に種々のアミノ酸誘導体を組み入れた化合物 を合成した結果, 最終的に図 42 に示すイミダプリル (161)がすぐれた ACE 阻害薬であることがわかった 以下，その合成法を概説する。

オキソイミダゾリジンカルボン酸 (154) は前述の方法 (図 31) でアスパラギン酸から合成できる。154を $t$-ブ
チルエステル体(155)に導き, 次いで $N$ メチル化によ り $N$-メチル体(156) とした後, $Z$ 保護基を切断して (4 S) -1-メチル-2-オキソイミダゾリジン-4-カルボン酸 $t$-ブチルエステル (157) とする。157に $(R)$-乳酸メチル エステルから導いた酸クロリド (158)を反応させると縮 合体(159)が得られる。これにL-ホモフェニルアラニン エチルエステルを縮合しマレイン酸を加えると立体配置 が反転し所望の全 $S$ 配置のマレイン酸塩 $(160)$ が結晶と して得れる。160を希塩酸で処理するとイミダプリル (161) が高収率で得られる。

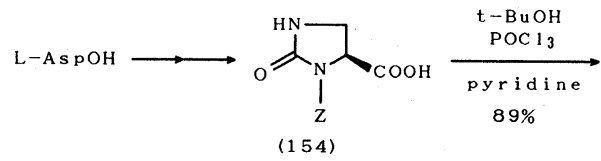

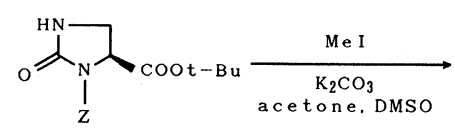

$90 \%$
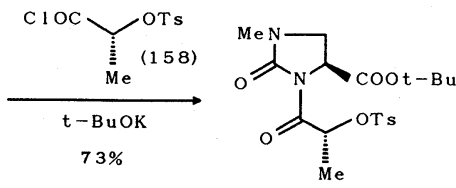

(159)

1) $\mathrm{H}_{2} \mathrm{~N} \underbrace{\mathrm{PaOE}}_{\mathrm{CH}_{2} \mathrm{CH}_{2} \mathrm{Ph}}$
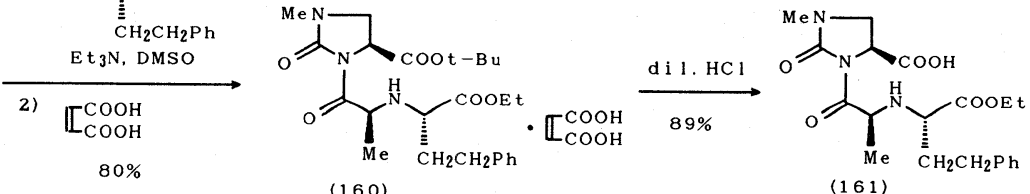

Fig. 42 
4. 4. TRH 系脳機能改善薬 視床下部ホルモンで ある TRH (162) は下垂体前葉を刺激して甲状腺刺激ホル モン (TSH)の分泌を促進する作用と中枢作用があること が知られている。最近, TRH 系化合物は脳機能改善薬 としても注目されている ${ }^{65)}$ が，その薬物としては，TSH 作用を減弱させ中枢作用を増強することが好ましいとさ れている。

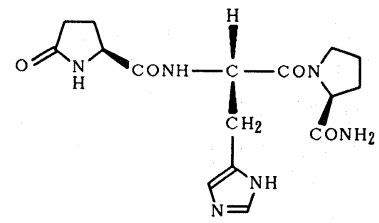

(162)

田辺製薬 (株)では，既にTRH を診断薬として開発し ているが，著者らはより好ましい脳機能改善薬を開発す ることを目的として，TRH のピログルタミン酸部分を 他のイミノ酸誘導体に変換した化合物を合成してきた。 その中から， $N$-メチル-4,5-ジヒドロオロット酸残基を 導入した化合物 (TA-0910) (169) が開発候補化合物とし て見い出された ${ }^{66)}$ 。 $N$-メチルジヒドロオロット酸 (167) は図 43 に示したようにアスパラギン酸から導いたジヒ ドロオロット酸(165)をラセミ化の起こらない条件によ り $N$-メチル化して合成できる。これをジペプチド(168) と縮合すると TA-0910(169)が得られる。
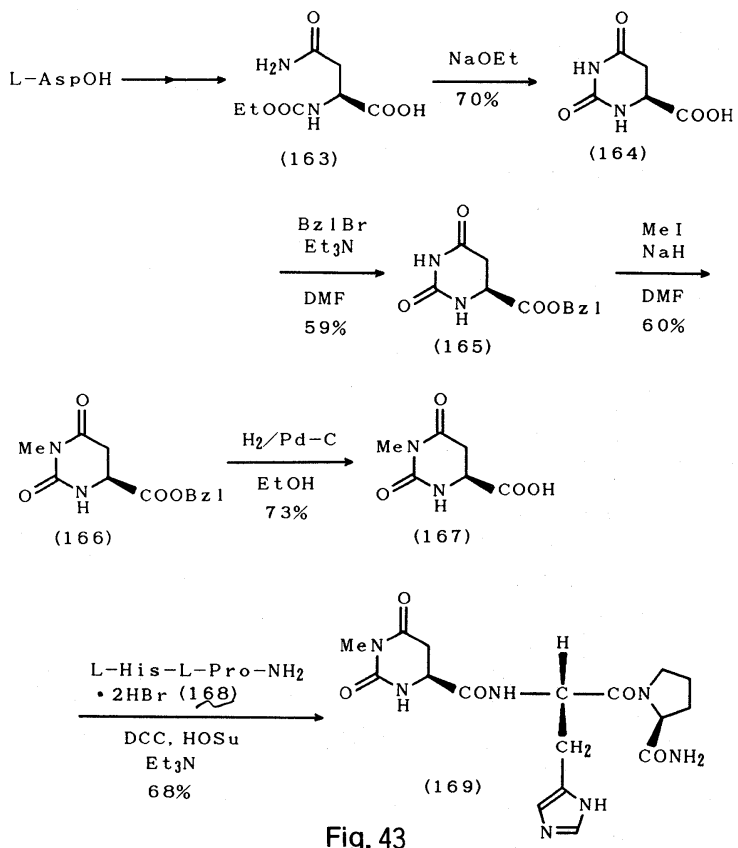

Fig. 43
4.5. 抗脂血薬 著者らは $\alpha$-イソシアノ酥酸誘導 体を用いた種々のアミノ酸およびへテロ環化合物の合成 と薬理活性探索研究において，下記オキサゾール化合物 (170)に注目した ${ }^{67}$ 。特に抗脂血薬の開発に的を絞って 各種誘導体を合成した結果, 図 44 に示す 2- (4-クロロ

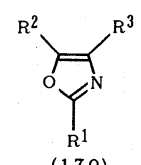

$\mathrm{R}^{1}: \mathrm{H}, \mathrm{A} 1 \mathrm{k}$ y 1 , A r y 1

$\mathrm{R}^{2}: \mathrm{A} 1 \mathrm{ky} 1$, Ary 1

$\left.R^{3}: H, A l k y\right], C O O R, \mathrm{CH}_{2} \mathrm{COOR}$

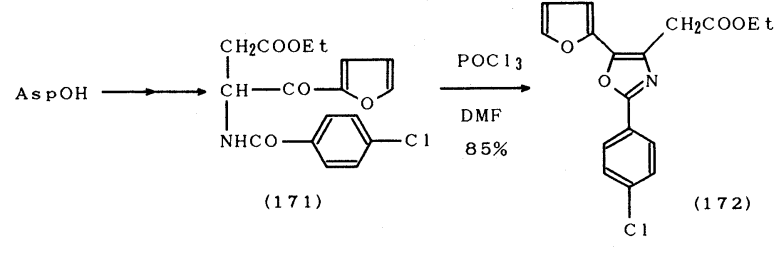

Fig. 44

フェニル)-5-(2-フリル)-4-オキサゾール䣷酸エチルエ ステル (TA-1801) (172) がすぐれた薬物であることがわ かった ${ }^{68)}$ 。さらに，その実用的合成法を検討し上記ルー 卜を確立した。

即ち，図44に示したようにAspartylation によりケト エステル化合物 (171)を合成し，これをVilsmeier 試薬 で脱水閉環すると目的とする TA-1801 (172)に導くこと ができる。

\section{5. おわりに}

以上， $\mathrm{L}$-アスパラギン酸は 5 個の官能基と不斉炭素を 備えていることから光学活性な反応活性種として有用で あることを述べてきた。特に，炭素-炭素結合形成によ るアスパラギン酸骨格の導入, 所謂 “Aspartylation”は 医薬品等の合成に利用価値の高いものと思われる。さら に，L-アスパラギン酸はフマール酸からバイオテクノロ ジーにより安価に生産されることから, 今後合成化学の 分野に扔いても，ますます機能性アミノ酸としての用途 が開かれるものと思われる。

本稿を書く機会を与えて下さった代表取締役社長千畑 一郎博士, 専務取締役研究開発本部長齋藤清一博士, な らびに取締役応用生化学研究所長土佐哲也博士に感謝い たします。

(平成 2 年 10 月 2 日受理) 


\section{文献}

1) Y. Izumi, I. Chibata, T. Itoh, Angew. Chem. Int . Ed.Engl. , 17, 176 (1978); 松本和男, 千畑一郎, 発酵と月:業, 41, 834 (1983) ; H. Yamada, S. Shimizu, Angew. Chem. Int. Ed. Engl., 27, 622 (1988)

2) V.A. Kleemann, Chemiker-Zeitung, 106, 151 (1982)

3) 代謝マップ, 日本生化学会編, 東京化学同人, 東京, 1980, p. 37, p.39

4) 牧 司, 森 威夫, 薬誌, 75, 604 (1955)

5) K. Harada, K. Matsumoto, J. Org. Chem., 31 , 2985 (1966) ; M. Tamura, K. Harada, Bull. Chem. Soc.Jpn. , 53, 561 (1980) ; P.J. Sinclair, D. Zhai, J. Reinbenspies, R.M. Williams, J. Am. Chem. Soc., 103, 1103 (1986)

6) I. Chibata, T. Tosa, T. Sato, Appl. Biochem. \& Biotech. , 13, 231 (1986) ; idem., "Comprehensive Biotechnology", ed. by Murray Moo-Young, Pergamon Press, Inc., Oxford, p.633

7）芳賀竹芳, 佐藤正常, 三浦近衛, 日特開昭 423290 (1967) ; R. Yoshioka, O. Ohtsuki, M. Senuma, T. Tosa, Chem. Pharm. Bull., 37, 883 (1989)

8）千畑一郎, 土佐哲也, 佐藤忠司, 川本浩三, 日特 開 昭 50-100289 (1975)

9) R.H. Mazur, J.H. Schlatter, A.H. Goldkamp, J. Am. Chem. Soc., 91, 2684 (1969); Y. Ariyoshi, T. Yamatani, N. Uchiyama, Y. Adachi, N. Sato, Bull. Chem. Soc. Jpm., 46, 1893 (1973) ; F.J. Vinick, S. Jung, J. Org . Chem ., 47, 2199 (1982); idem., Tetrahedron Lett., 23, 1315 (1982); J.S. Tou, B.D. Vineyard, J. Org. Chem., 50, 4982 (1985) ; C. Fuganti, P. Grasselli, L. Malpezzi, ibid . 51, 1126 (1986) ; P. Duhamel, B. Goument, J.C. Ploquevent, Tetrahedron Lett., 28, 2595 (1987) ; Y. Isoya, M. Ohmori, T. Ichikawa, K. Mori, ibid., 1979, 2611 ; K.Oyama, S. Nishimura, Y. Nonaka, K. Kihara, T. Hashimoto, J. Org. Chem., 46, 5241 (1981)

10) S. Maeda, M. Suzuki, T. Iwasaki, K. Matsumoto, Y. Iwasawa, Chem. Pharm. Bull., 32, 2536 (1984) ; Y. Ozaki, S. Maeda, T. Iwasaki, K. Matsumoto, A. Odawara, Y. Sasaki, T. Morita, ibid., 31, 4417 (1983)

11) T.F. Buckley III, H. Rapoport, J. Am. Chem. Soc., 103, 6157 (1981) ; C.G. Knudsen, H. Rapoport, J. Org. Chem., 48, 2260 (1983) ; D.E. McClure, P.K. Lumma, B.M. Arison, J.H. Jones, J.J. Baldwin, J. Org. Chem . 48, 2675 (1983) ; M. Dufour, P. Jouin, J. Poncet, A. Pantaloni, B. Castro, J. Chem. Soc., Perkin Trans. 1, 1986, 1895 ; K. Soai, A. Ookawa, J. Chem. Soc., Chem.
Commun., 1986, 412

12) T. Moriya, M. Seki, H. Kubota, K. Matsumoto, Chem. Express., 1, 157 (1986)

13) M. Seki, T. Moriya, K. Matsumoto, Agric. Biol. Chem., 51, 3033 (1987)

14) T. Wakamiya, T. Shiba, T. Kaneko, Bull. Chem. Soc.Jpn . , 45, 3668 (1972) ; T. Teshima, T. Ando, T. Shiba, ibid., 53, 1191 (1980); M. Hirama, T. Shigemoto, S. Ito, J. Org. Chem ., 52, 3342 (1987); W.R. Roush, J.A. Straub, R.J. Brown, ibid . , 52, 5127 (1987)

15) M. Seki, H. Kubota, T. Moriya, M. Yamagishi, S. Nishimoto, K. Matsumoto, Chem. Pharm. Bull., 34, 4516 (1986)

16）松浦秀治，化学と生物，28，213 (1990)

17）松本和男, 守屋多聞, 鈴木 護, 有合化, 43, 764 (1985)

18) M. Suzuki, T. Iwasaki, K. Matsumoto, K. Okumura, Synth. Commun., 2, 237 (1972) ; M. Suzuki, T. Iwasaki, M. Miyoshi, K. Okumura, K. Matsumoto, J. Org. Chem. ,38, 3571 (1973)

19) Z.H. Israili, E.E. Smissman, J. Chem. Eng. Data., 22, 357 (1977)

20) J. Lepschy, G. Höfle, L. Wilschowitz, W. Steglich, Liebig. Ann. Chem., 1974, 1753

21) K. Meguro, H. Tawada, Y. Sugiyama, Y. Fujita, Y. Kawamatsu, Chem. Pharm. Bull., 34, 2840 (1986)

22) D. Seebach, D. Wasmuth, Angew. Chem. Int. Ed. Engl., 20, 971 (1981)

23) J.D. Aebi, D. Seebach, Helv . Chim . Acta, 68, 1507 (1985)

24) U. SchÖllkopf, H.H. Haupberg, I. Hoppe, M. Segal, U. Reiter, Angew. Chem. Int.Ed.Engl., 17, 117 (1978)

25）松本和男, 岩崎為雄, 未発表

26) Y. Ozaki, T. Iwasaki, H. Horikawa, M. Miyoshi, K. Matsumoto, J. Org. Chem., 44, 391 (1979)

27) K. Matsumoto, H. Horikawa, T. Iwasaki, M. Miyoshi, Chem. \& Ind ., 1978, 920; T. Iwasaki, H. Horikawa, K. Matsumoto, M. Miyoshi, Tetrahedron Lett . , 19, 4799 (1978)

28) J.P. Wolf, H. Rapoport, J. Org. Chem ., 54, 3164 (1989)

29) J.E. Baldwin, M.G. Moloney, M. North, J. Chem . Soc. Perkin Trans. 1 1989, 833 ; idem., Tetrahedron, 45, 6309 (1989)

30) idem., ibid., 45, 6319 (1989)

31) G.J. McGarvey, R.N. Hiner, Y. Matsubara, T. Oh, Tetrahedron Lett., 24, 2733 (1983); G.J. McGarvey, J.M. Williams, R. N. Hiner, Y. Matsubara, T. Oh, J. Am. Chem. Soc., 108, 4943 (1986)

32) M. Namikoshi, K.L. Rinehart, Tetrahedron Lett., 30, 4349 (1989) 
33) Y. Takahashi, S. Hasegawa, T. Izawa, S. Kobayashi, M. Ohno, Chem. Pharm. Bull., 34, 3020 (1986)

34) Y. Takahashi, H. Yamashita, S. Kobayashi, M. Ohno, ibid., 34, 2732 (1986)

35）松本和男, 守屋多聞, 未発表

36) H. Kubota, T. Moriya, K. Matsumoto, Chem. Pharm. Bull., 38, 570 (1990)

37) I. Chibata, T. Kakimoto, J. Kato, Appl. Microbiol., 13, 638 (1965)

38) H. Dugas, C. Penny, "Bioorganic Chemistry", Springer Verlag, New York, 1981, pp.443-444

39) K. Matsumoto, K. Harada, J. Org. Chem., 33, 4526 (1968)

40) M. Seki, T. Moriya, K. Matsumoto, Agric. Biol. Chem., 48, 1251 (1984)

41) T. Kolasa, Synthesis, 1983, 539

42) T. Iwasaki, H. Yamazaki, T. Nishitani, Y. Masaki, T. Sato, Chem. Pharm. Bull. , 投稿中

43) D.H.R. Barton, Y. Herve, P. Potier, J. Thierry, J. Chem. Soc., Chem. Commun., 1984, 1298 D.H.R. Barton, J. Guilhem, Y. Herve, P. Potier, J. Thierry, Tetrahedron Lett., 28, 1413 (1987); D.H.R. Barton, Y. Herve, P. Potier, J. Thierry, Tetrahedron, 43, 4297 (1987)

44) W.G. Reifenrath, D.J. Bertelli, M.J. Micklus, D.S. Fries, Tetrahedron Lett., 1976, 1959

45) J.E. Nordlander, M.J. Payne, F.G. Njoroge, V.M. Vishwanath, G.R. Han, G.D. Laikos, M.A. Balk, J. Org. Chem., 50, 3619 (1985)

46) D.G.メリロ，日特開 昭63-5087 (1988)

47) D.D. Keith, J.A. Tortora K. Ineichen, W. Leimgruber, Tetrahedron, 31, 2633 (1975) ; M.G.P. Blanchard, J.L. Fourrey, M. Robert-Gero, J. Am . Chem. Soc., 105, 7638 (1983) ; J.E. Baldwin, C. Lowe, C.J. Schofield, Tetrahedron Lett., , 27, 3461 (1986) ; H.L. Sham, H. Stein, J. Cohen, J. Chem. Soc., Chem. Commun., 1987, 1792 ; R.M. Valerio, P.F. Alewood, R.B. Jones, Synthesis., 1988, 786 ; D. Wernic, J. DiMaio, J. Adams, J. Org. Chem., 54, 4224 (1989)

48) J.E. Baldwin, A. Flinn, Tetrahedron Lett., 28, 3605 (1987)

49) M. Waki, Y. Kitajima, N. Izumiya, Synthesis, 1981, 266

50) J.M. Scholtz, P.A. Bartlett, ibid., 1989, 542

51) F. Schneider, Ann. Chem., 529, 1 (1937)

52) 米田直人, 藤井利幸, 梅田昌昭, 安尾悠紀, 田口 善彦，奥村健太郎，薬誌，89，98 (1969)

53) K. Okumura, T. Iwasaki, T. Okawara, K. Matsumoto, Bull. Inst. Chem. Res., Kyoto Univ. , 50, 209 (1972)
54) D. Gani, W. Young, J. Chem. Soc., Perkin Trans. 1, 1983, 2393

55）松岡 学, 国仙谷良男, 日特開 昭 50-58405 (1975)

56) Y. Murakami, K. Koga, S. Yamada, Chem. Pharm. Bull., 26, 307 (1978)

57) T. Miyazawa, E. Akita, T. Ito, Agric. Biol. Chem., 40, 1651 (1976)

58) H. Maeda, M. Suzuki, H. Sugano, K. Matsumoto, Synthesis, 1988, 401

59) H. Laborit, B. Weber, J.M. Jouany, P. Niaussat, C. Baron, Presse Med ., 66, 2125 (1958) ; H. Laborit, B. Weber, P. Niaussat, J.M. Jouany, G. Guiot, J. Zawadoski, C. Baron, Anesth. Analg. Reanim, 15, 480 (1958) ; H. Laborit, B. Weber, J.M. Jouany, P. Niaussat, B. Broussolle, M. Reynier, C. Baron, ibid, 16, 379 (1959)

60) M. Wagatsuma, M. Seto, T. Miyagishima, M. Kawazu, T. Yamaguchi, S. Ohshima, J. Antibiot., 36, 147. (1983)

61) B.G. Christensen, Chemistry in Britain, 1989, 371

62) T.N. Salzmann, R.W. Ratcliffe, B.G. Christensen, F. A. Bouffard, J. Am. Chem. Soc ., 102, 6163 (1980)

63) H. Gavras, H.R. Brunner, G.A. Turini, New Engl. J. Med., 298, 991 (1978) ; H. Gavras, J. Biollaz, B. Waeber, Lancet, 2, 543 (1981) ; A.C. Jenkins, G.R. Dreslinski, S.S. Tadross, J. Cardiovasc. Pharmacol., 7, 896 (1985)

64) K. Hayashi, K. Nunami, J. Kato, N. Yoneda, M. Kubo, T. Ochiai, R. Ishida, J.Med. Chem., 32, 289 (1989) ; H. Kubota, K. Nunami, M. Yamagishi, S. Nishimoto, K. Hayashi, Chem. Phorm. Bull, 投稿中

65) N.P. Plotnikoff, A.J. Jr. Prange, G.R. Breese, M.S. Andersen, I.C. Wilson, Science, 178, 417 (1972) ; J. Boler, F. Enzmann, K. Folker, C. Y. Bowers, A.V. Shally, Biochem. Biophys. Com mun., 37, 705 (1969) ; R. Burgus, T.F. Dunn, D. Desiderio, D. N. Ward, W. Vale, R. Guillemin, Nature (London), 226, 321 (1970)

66) M. Suzuki, H. Sugano, K. Matsumoto, M. Yama mura, R. Ishida, J. Med. Chem ., 33, 2130 (1990)

67) T. Moriya, S. Takabe, S. Maeda, K. Matsumoto, K. Takashima, T. Mori, S. Takeyama, J. Med. Chem., 29, 333 (1986) ; M. Seki, T. Moriya, K. Matsumoto, K. Takashima, T. Mori, A. Odawara, S. Takeyama, Chem. Pharm. Bull., 36, 4435 (1988)

68) T. Moriya, M. Seki, S. Takabe, K. Matsumoto, K. Takashima, T. Mori, A. Odawara, S. Takeyama, J. Med. Chem., 31, 1197 (1988) 